고엔탈피 열유동 발생용 고주파 유도결합 플라즈마 토치의

최적 설계변수 해석

서준호*

\title{
Optimum design analysis of ICP(Inductively Coupled Plasma) torch for high enthalpy thermal plasma flow
}

Jun-Ho Seo*

\begin{abstract}
In this paper, optimum design process of ICP (Inductively Coupled Plasma) torch, which has been used widely in aerospace application, such as supersonic plasma wind tunnel, is presented. For this purpose, the behaviors of equivalent circuit parameters (equivalent resistance and inductance, coupling efficiency) were investigated according to the variations of torch design parameters (frequency, $f$, confinement tube radius, $R$ and coil turn numbers, $M$ in the basis of analytical and numerical MHD (Magneto Hydro-Dynamics) models combined with electrical circuit theory. From the results, it is found that equivalent resistance is increased with the increase of $f$ values but vice versa for equivalent inductance. For elevated values of $R$ and $N$, however, both parameters tend to increase. Based on these observations, ICP torch with a power level of $10 \mathrm{~kW}$ can be optimized at the design ranges of $f=4 \sim 6 \mathrm{MHz}, R=17 \sim 25 \mathrm{~mm}$ and $N=3 \sim 4$ to maximize the electrical coupling efficiency, which is the ratio of equivalent resistance to equivalent inductance.
\end{abstract}

\section{초 록}

초음속 플라즈마 풍동 등, 항공우주 응용을 위한 고순도, 고엔탈피 열유동 발생 장치로서 널리 쓰이고 있는 유도결합 플라즈마 토치에 대해, 전기회로 이론과 결합된 해석적 및 수 치해석적 자기유체역학 모델을 이용하여 토치 설계변수(주파수 $f$, 가둠관 반지름 $R$ 및 코일 감은수 $M$ 변화에 따른 전기적 특성 변수(등가 저항, 등가 인덕턴스 및 결합효율)의 거동을 추적함으로써 최적 설계 변수해석을 수행하였다. 계산 결과, 등가저항은 $f, R$ 및 $N$ 이 증가 함에 따라 커지는 반면, 등가 인덕턴스는 $f$ 가 증가할수록 작아지지만 $R$ 과 $N$ 의 증가에 대 해서는 커지는 경향이 있음을 파악하였다. 이로부터, $10 \mathrm{~kW}$ 급 고주파 유도결합 플라즈마 토치의 경우, 결합효율을 극대화시키는 최적의 주파수, 가둠관 반지름 및 코일 감은수의 범 위를 각각 $f=4 \sim 6 \mathrm{MHz}, R=17 \sim 25 \mathrm{~mm}$ 및 $N=3 \sim 4$ 로 추정하였다.

Key Words : Inductively Coupled Plasma(유도결합 플라즈마), Coupling Efficiency(결합 효율), Plasma wind tunnel(플라즈마 풍동), Optimum Design(최적 설계)

\footnotetext{
† 2011년 10월 31일 접수 2012년 2월 27일 심사완료

* 정회원, 전북대학교 고온플라즈마응용연구센터

교신저자, jhseo@jbnu.ac.kr

전라북도 전주시 덕진구 덕진동 1가 664-14
} 


\section{I. 서 론}

최근, 직류(DC) 또는 고주파(RF) 유도결합 방 식으로 공급되는 전기 에너지를 사용하여 고온, 고엔탈피의 이온화 된 플라즈마 젯트를 만들어낼 수 있는 플라즈마 토치들이 우주선의 지구 재진 입 시 겪는 공력가열 현상 모사와 우주 추진체 개발을 위하여 많이 연구되고 있다[1-5]. 이 중, 고주파 유도결합 방식의 플라즈마 토치는 Fig. 1 에 설명된 바와 같이, (1)유도 코일에 인가된 고 주파 전류 $I_{0}$ 가 (2)패러데이(Faraday) 법칙에 따 라 코일 내부에서 시변 자기장 $B$ 를 유기시키고, (3)이 시변 자기장 $B$ 가 암페어(Ampere) 법칙에 따라 다시 가둠관 내에서 전기장 $E_{\theta}$ 를 회전방향 으로 유기하도록 하여, 가둠관 내 이온과 전자들 을 가속시켜 주변 기체들과 충돌에 의한 이온화 를 지속적으로 일으키게 함으로써, 와전류 $I_{p}$ 를 발생시키고 (4)이 와전류 $I_{p}$ 에 의한 주울(Joule) 열 발생을 통해 가둠관을 지나는 기체가 이온화 된 열유체 상태가 되도록 에너지와 플라즈마 기 체를 지속적으로 공급하도록 고안된 장치이다. 이와 같은 플라즈마 발생 및 유지 원리 덕택에, 고주파 유도결합 플라즈마 토치는 유도코일 내부 원통형 가둠관을 흘러 지나가는 유체에 비접촉 방식으로 에너지를 전달해 줄 수 있어서, 우주 추진체용 플라즈마 추력기의 직류 아크젯 유동을 재가열하여 추진력을 높이는 2 차 버너로 사용하 거나 지구 재진입 비행물체의 공력가열 현상 모 사를 위한 초음속 플라즈마 풍동용 고엔탈피 열 유동 토치로 활용될 수 있다[1-5].

반면, 가둠관을 지나면서 이온화된 열유체에 공급되는 전기 에너지는 변압기 원리에 따라 유 도코일로부터 발생되는 시변 전자기장과 이 시변 전자기장이 유기시키는 와전류를 매개로 전달되 는 방식이므로, 해당 응용 목적별로 요구되는 고 주파 전력을 효율적으로 전달하기 위해서는, 주 파수, 코일 감은수 및 가둠관 반지름 등과 같은 고주파 전원과 토치의 주요 설계 변수들을 최적 화할 필요가 있다. 특히, 변압기 원리 상, 다수의 감은수를 가지는 유도코일에 비하여, 감은수가 1 회로 간주되는 원통형 전도체 형태에 가까운 유 도결합 플라즈마는 낮은 저항 성분과 상대적으로 큰 유도 인덕턴스 및 결합 인덕턴스 성분을 가지 게 되므로, 플라즈마 출력으로의 전력변환 효율 을 높이기 위해선, 고주파 전원의 출력단에서 느껴

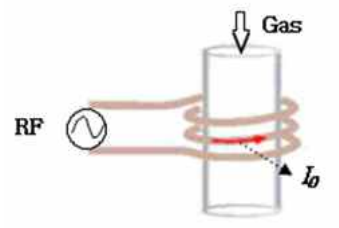

(1)

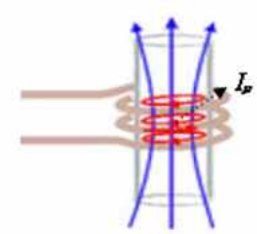

(3)

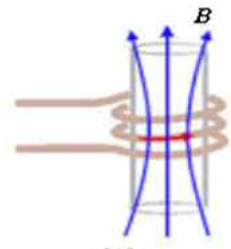

(2)

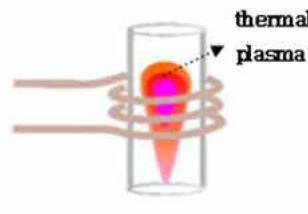

(4)
Fig. 1. A schematic explanation for principle of inductively coupled plasma formation

지는 등가 플라즈마 저항은 높이고, 등가 인덕턴 스는 줄이는 토치 설계가 요구된다.

이를 위해, 본 논문에서는 $10 \mathrm{~kW}$ 급 고주파 유도결합 플라즈마 토치를 대상으로 하여, $\mathrm{RF}$ 주 파수, 가둠관 반지름 및 코일 감은수와 같은 핵 심 설계변수 변화에 따른 등가 플라즈마 저항, 등가 인덕턴스, 코일 전류 및 결합효율과 같은 유도결합 플라즈마의 전기적 특성 변화를 해석적 방법과 전산해석 결과의 비교를 통하여 살펴보고 그 결과를 바탕으로 해당 설계변수들의 최적값 범위를 제시하였다. 여기에 사용된 해석적 방법 으로서는 M. P. Freeman 등이 [6], 유도결합 플 라즈마를 토치 가둠관 반지름 내에서 플라즈마 반지름 $r_{0}$ 와 유도코일 길이 $l$ 만큼의 길이를 갖 는 원통형 전도체로 가정하고, 유도코일에 흐르 는 전류를 가둠관 경계에서의 표면전류(sheet current)로 전환한 다음 이를 경계조건으로 삼 아 제안한 원통형 전도체 모델을 사용하였다. 이 모델을 바탕으로 1차원 열전도 방정식과 등 가회로 이론을 결합시켜, 플라즈마 반지름, 플 라즈마 온도, 반지름방향 전자기장 분포, 플라 즈마 출력 및 가둠관 내 자기에너지에 대한 해 석해를 유도하였으며 그 결과로부터, 등가 인덕 턴스와 등가 저항을 구하는 방식을 시도하였다. 수치해석의 경우, A. Merkhouf 등이[7] 제안한 바 있는 유도결합 플라즈마 토치와 고주파 전 원 시스템에 대한 통합된 수치해석 모델을 바 탕으로, 주파수 고정 방식의 고주파 전원을 가 정하여 등가 인덕턴스 및 등가 저항을 플라즈 마 유동장과 함께 계산하였다. 


\section{II. 본 론}

\section{1 관련 이론}

\subsection{1 해석적 해}

반지름 $R$ 인 가둠관 내에 발생한 고주파 유도 결합 플라즈마는, 유동에 의한 모양 발달이 없다 면, Fig. 2에 묘사된 바와 같이 가둠관을 길이 $l$ 만큼 감고 있는 유도코일에 의해 와전류가 회전 방향으로 유기되는 내부 반지름 $r_{0}$ 를 가지는 원 통형 전도체처럼 다룰 수 있다. Fig. 2와 같이 고 주파 유도결합 플라즈마를 원통형 전도체로 단순 가정할 경우 잘 알려진 유도가열 원리에 따라 가 둠관 내 1차원 전자기장 해석을 할 수 있으며 이 를 바탕으로 플라즈마의 표피깊이(skin depth)에 서 대부분 일어나는 주울 열 분포에 대한 계산이 가능해진다.

예를 들어 M. P. Freeman 등은 가둠관 주위를 일정한 간격으로 감고 있는 유도코일을 솔레노이 드처럼 생각하여 Fig. 2와 같이 가정된 원통형 플라즈마 내에 유기되는 축방향 시변자기장 세기 $H(r, t)$ 에 대해 식(1)과 같은 표현식을 유도한 바 있다[6].

$$
\frac{d^{2} H}{d r^{2}}+\frac{1}{r} \frac{d H}{d r}-2 j \pi f \sigma \mu_{0} H=0
$$

여기서 $f$ 는 유도코일에 인가한 고주파 전류의 주파수이며 $\sigma$ 는 원통형 전도체로 가정된 플라즈 마의 전기전도도 $\mu_{0}$ 는 투자율이다. 또한 $j$ 는 시 간 $t$ 에 대해 주파수 $f$ 를 가지고 정현적으로 변 화하는 자기장 세기 $H(r, t)$ 에 대한 복소수 표현 식 $H(r, t)=H(r) \exp (2 j \pi f t)$ 로부터 나오는 허수 단위이다. 식 (1)에 대한 경계조건은 식 (2)와 같 이 주어진다.

$$
\begin{aligned}
& H=0 \quad \text { at } r=0 \\
& H=H_{0} \quad \text { at } r=r_{0}
\end{aligned}
$$

자기장 세기 $H$ 에 대한 식 (1)의 해는 잘 알려진 Kelvin 함수의 형태로 식 (3)과 같이 주어지며 플라즈마 내에 유도되는 전기장 $E_{\theta}$ 는 Maxwell 방정식으로부터 아래 식 (4)와 같이 표현될 수 있다.

$$
\begin{gathered}
H=H_{0} \frac{\operatorname{Ber}(\rho)+j \operatorname{Bei}(\rho)}{\operatorname{Ber}\left(\rho_{0}\right)+j \operatorname{Bei}\left(\rho_{0}\right)} \\
E_{\theta}=-\frac{\sqrt{2}}{\sigma \delta} H_{0} \frac{\operatorname{Ber}(\rho)^{\prime}+j \operatorname{Bei}(\rho)^{\prime}}{\operatorname{Ber}\left(\rho_{0}\right)+j \operatorname{Bei}\left(\rho_{0}\right)}
\end{gathered}
$$

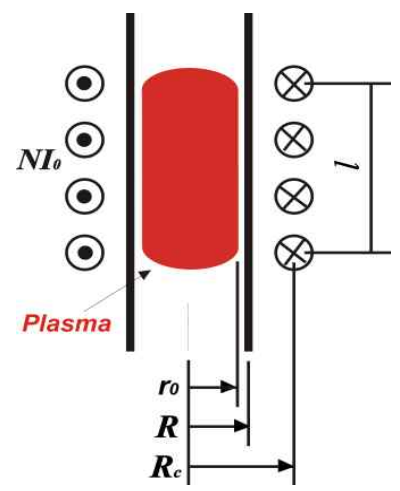

Fig. 2. Metallic cylinder model for inductively coupled plasma[6]

여기서 특성변수 $\rho$ 및 $\rho_{0}$ 는 플라즈마의 표피깊 이 $\delta$ 를 이용하여 반지름방향 거리 $r$ 및 플라즈 마 반지름 $r_{0}$ 를 식 (5)와 같이 변수 치환한 것이 며 식 $(4)$ 에서 윗 첨자 '은 변수 $\rho$ 에 대한 전미 분을 나타낸다.

$$
\rho=\sqrt{2} \frac{r}{\delta}, \rho_{0}=\sqrt{2} \frac{r_{0}}{\delta}
$$

플라즈마의 표피깊이 $\delta$ 는 주파수 $f$ 와 플라즈마 전기전도도 $\sigma(T)$ 의 함수로서 식 (6)과 같이 표 현된다.

$$
\delta=\sqrt{\frac{1}{\pi f \mu_{0} \sigma(T)}}
$$

$H_{0}$ 는 플라즈마 반지름 $r_{0}$ 에서의 자기장 세기를 뜻한다.

한편 이온화된 기체로서의 플라즈마는 예를 들어 $8,000 \mathrm{~K}$ 수준의 $\mathrm{Ar}$ 플라즈마의 경우 금속 전도체 수준의 높은 전기전도도와 열전도도를 가 진다[8]. 따라서 식 (6)과 같이 주어지는 원통형 플라즈마 표피깊이에서 발생된 주울 열은 플라즈 마 내부 중심축 방향에 대해 상대적으로 빨리 전 달될 것이기 때문에 원통형 플라즈마 내 반지름 방향 온도 분포는 별다른 온도 구배 없이 8,000 $\mathrm{K}$ 이상의 고온을 비교적 일정하게 유지할 것이 라 생각할 수 있다. 반면, 원통형 플라즈마와 가 둠관 사이의 영역에서는 경계인 가둠관 벽의 냉 각에 따라 급격한 온도구배가 형성된다. $\mathrm{Ar}$ 기체 의 온도에 대한 전기전도도 특성을 살펴보면 약 $5,000 \mathrm{~K}$ 이하에선 거의 0 에 가까운 값을 가지므 로[8], 온도구배가 급격히 이루어지는 원통형 플 라즈마와 가둠관 사이의 영역에서는 별다른 주울 열 발생 없이 플라즈마로부터 가둠관 쪽으로 반 
지름방향 단순 열전도만 일어난다고 가정할 수 있다. 이와 같은, 원통형 전도체로 간주된 고주파 유도결합 플라즈마와 가둠관 사이의 온도분포에 대한 가정을 바탕으로 Raizer 등은[9] Fig. 2의 원통형 플라즈마 모형에 대해 플라즈마 내부에서 일어나는 대류 및 복사에 의한 열전달을 무시하 고 플라즈마와 가둠관 사이의 반지름방향 열전도 에 의한 평형만을 고려하여 $H_{0}$ 및 코일 전류 $I_{0}$ 와 플라즈마 온도 $T_{0}$ 사이의 관계를 식 (7)과 같 이 유도한 바 있다.

$$
\frac{1}{4} H_{0}^{2}=\frac{1}{4}\left(\frac{N I_{0}}{l}\right)^{2}=\int_{0}^{T_{0}} k(T) \sigma(T) d T
$$

또한 플라즈마 반지름 $r_{0}$ 에서 가둠관 쪽으로 열 전도를 통해 빠져나가는 열량과 플라즈마 출력 $P_{0}$ 가 같다는 조건 하에 플라즈마 반지름 $r_{0}$ 를 플 라즈마 출력 $P_{0}$ 및 온도 $T_{0}$ 의 함수로 식 (8)과 같이 유도하였다.

$$
r_{0}=R \exp \left(-\frac{2 \pi l}{P_{0}} \int_{T_{w}}^{T_{0}} k(T) d T\right)
$$

여기서 가둠관에서의 온도 $T_{w}$ 은 0 이라고 가정하 였으며, $k(T)$ 는 플라즈마의 열전도도로서 온도 의 함수이다. 식 (7)과 (8)에서 $l$ 은 플라즈마 길이 이며 Fig. 2에 보인 바와 같이 코일 길이와 같다. 본 논문에서는 길이 $l$ 이 코일 감은수 $N$ 및 코일 간 간격 $d_{c}$ 에 대해 아래 식 (9)과 같은 관계를 가 진다고 가정하였다.

$$
l=(N-1) d_{c}
$$

플라즈마 출력 $P_{0}$ 는 식 (4)로 주어지는 플라즈마 내 전기장 $E_{\theta}$ 의 분포를 식 $(10)$ 에 나타낸 바와 같이 플라즈마 반지름 $r_{0}$ 까지 적분함으로써 구할 수 있다.

$$
P_{0}=\pi \sigma l \int_{0}^{r_{0}} E_{\theta} E_{\theta}^{*} r d r
$$

적분 기호 내 * 표시는 전기장 $E_{\theta}$ 의 복소공액 (complex conjugate)이다. 플라즈마 출력 $P_{0}$ 가 고정된 값 $10 \mathrm{~kW}$ 로 주어지면 식 (8)로부터 플라 즈마 반지름 $r_{0}$ 는 플라즈마 온도 $T_{0}$ 의 함수가 된다. 이를 식 (10)의 우변에 대입하여 임의의 $T_{0}$ 값에 따라 계산하고 그 결과값을 좌변과 비 교함으로써 $10 \mathrm{~kW}$ 로 고정된 값 $P_{0}$ 를 만족시키 는 플라즈마 온도 $T_{0}$ 및 플라즈마 반지름 $r_{0}$ 를
찾을 수 있다.

한편 플라즈마와 가둠관 사이에서 주울 열 발 생이 없어 자기에너지의 손실이 없다고 가정하면 $H_{0}$ 는 $r=r_{0}$ 에서 $r=R$ 까지의 자기장 세기를 나 타낸다고 할 수 있으므로 식 (3)으로 주어지는 플라즈마 내 자기장 세기 $H$ 의 분포를 식 (11)에 따라 가둠관 까지 적분함으로써 토치 내 총 이용 가능한 자기 에너지 $P_{m a g}$ 를 구할 수 있다.

$$
P_{\text {mag }}=2 \pi^{2} f \mu_{0} l \int_{0}^{R} H H^{*} r d r
$$

고정된 플라즈마 출력 $P_{0}$ 로부터 원통형 플라즈 마의 온도 $T_{0}$ 및 반지름 $r_{0}$ 가 결정되면 식 (3)과 (7)을 식 (11)에 대입하여 $P_{m a g}$ 를 계산할 수 있 다. 마지막으로 Fig. 3의 등가회로로부터 플라즈 마 출력 $P_{0}$ 및 토치 내 총 자기에너지 $P_{m a g}$ 는 등가 저항 $R_{e q}$ 등가 인덕턴스 $L_{e q}$ 및 코일 전류 $I_{0}$ 에 대해 식 (12)와 식 (13)의 관계를 가짐을 알 수 있다.

$$
\begin{aligned}
& P_{\text {mag }}=\pi f L_{e q} I_{0}^{2} \\
& P_{0}=\frac{1}{2} R_{e q} I_{0}^{2}
\end{aligned}
$$

식 (12) 및 식 (13)의 코일 전류 $I_{0}$ 와 $P_{m a g}$ 에 대 해 각각 식 (7)과 식 (11)을 대입하면 등가 인덕 턴스 $L_{e q}$ 와 등가 저항 $R_{e q}$ 를 식 (14), (15)와 같 이 나타낼 수 있다.

$$
\begin{aligned}
& L_{e q}=\frac{P_{m a g}}{\pi f I_{0}^{2}} \\
& R_{e q}=\frac{2 P_{0}}{I_{0}^{2}}
\end{aligned}
$$

덧붙여 토치 내 총 이용가능한 자기 에너지 $P_{m a g}$ 에 대한 플라즈마 출력 $P_{0}$ 의 비로 주어지는 결합효율 $\eta_{c}$ 를 식 (16)처럼 표현할 수 있다.

$$
\eta_{c}=\frac{P_{0}}{P_{\text {mag }}}=\frac{R_{e q}}{2 \pi f L_{e q}}
$$

따라서 플라즈마 온도 $T_{0}$ 를 따로 가정하지 않고 도 출력 $P_{0}$ 를 유지시키기 위해 필요한 토치 내 자기에너지 $P_{m a g}$, 코일 전류 $I_{0}$ 및 전기적 특성 변수 $L_{e q}, R_{e q}, \eta_{c}$ 사이의 상호관계를 살펴 볼 수 있게 된다. 


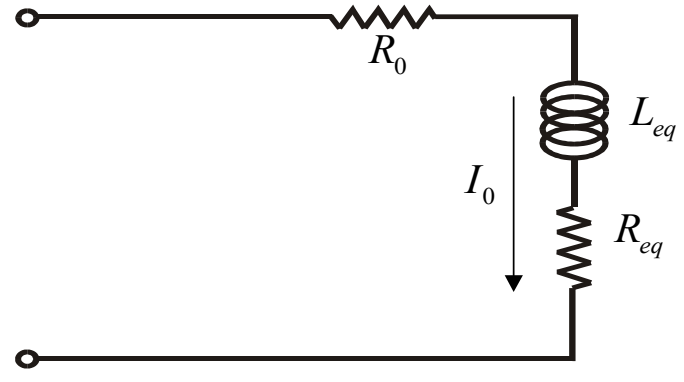

Fig. 3. Equivalent circuit for inductively coupled plasma

\subsection{2 자기유체역학(MHD) 전산 모형}

2.1.2.1 유도결합 플라즈마 토치 전산 모형, 운전 조건 및 기본 가정

원통형 전도체로 묘사된 해석적 해와 달리 플 라즈마 유체와 전자기장과의 상호작용을 묘사하 기 위해 자기유체역학(MHD) 및 전자기와 관련 된 비선형 편미분 방정식들을 이용하여 수치해석 을 시도하였다. Fig. 4는 수치해석에 사용된 유도 결합 플라즈마 토치의 개략도를 나타내고 있으며 플라즈마 운전조건 및 토치 설계변수 범위를 Table 1에 제시하였다.

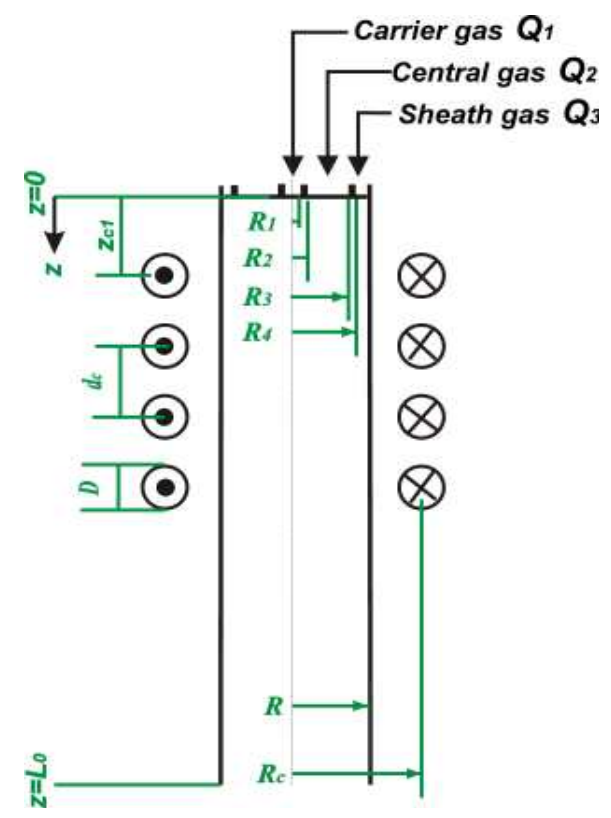

Fig. 4. Computational model for numerical analysis based on 2-D MHD equations.
Table 1. Design and operating parameters

\begin{tabular}{cc}
\hline Parameters & Values \\
\hline$R_{1}[\mathrm{~mm}]$ & 2 \\
$R_{2}[\mathrm{~mm}]$ & 4 \\
$R_{3}[\mathrm{~mm}]$ & $\mathrm{R}_{4}-2$ \\
$R_{4}[\mathrm{~mm}]$ & $\mathrm{R}-(2 \sim 3)$ \\
$R[\mathrm{~mm}]$ & $10 \sim 35$ \\
$R_{c}[\mathrm{~mm}]$ & $\mathrm{R}+13$ \\
Frequency, $f[\mathrm{MHz}]$ & $1 \sim 6$ \\
Turn Numbers, $N$ & $3 \sim 5$ \\
$d c[\mathrm{~mm}]$ & 15 \\
Torch Length, $L_{0}[\mathrm{~mm}]$ & 150 \\
1st Coil Location, $Z_{c, 1}[\mathrm{~mm}]$ & 10 \\
RF Power, $\mathrm{P}_{0}[\mathrm{~kW}]$ & 10
\end{tabular}

Ar flow rate, $Q$ [slpm] $Q_{1}=1, Q_{2}=3, Q_{3}=21$

또한 본 논문의 자기유체역학(MHD) 전산 모형 에 사용된 가정은 다음과 같다.

(1) 정상상태 층류

(2) 2차원 축대칭 온도장 및 속도장

(3) 변위전류를 무시한 2차원 전자기장

(4) 플라즈마 내 점성에 의한 소산 및 중력에 의한 영향 무시

(5) 광학적으로 소하며 국소열평형 상태의 플 라즈마

\subsubsection{2 지배방정식}

유체로서의 플라즈마 거동을 묘사하기 위해 질량, 운동량, 에너지 보존 방정식을 고주파 코일 에 의해 플라즈마 내에 발생하는 전자기장을 알 아보기 위해 자기벡터 포텐샬 $A$ 에 관한 방정식 을 사용하였다. 정상상태의 2차원 축대칭인 원통 형 좌표계 $(r, \theta, z)$ 에서 이들 각 유체방정식 및 전자기장 방정식들을 다음과 같이 표현하였다.

(1) 질량 연속방정식

$$
\frac{\partial}{\partial z}(\rho u)+\frac{1}{r} \frac{\partial}{\partial r}(r \rho v)=0
$$

여기서 $\rho$ 는 밀도, $u$ 와 $v$ 는 각각 축방향과 반경 방향의 플라즈마 속도이다.

(2) 운동량 보존방정식 
: 축 $(z)$ 방향

$$
\begin{aligned}
& \rho\left(u \frac{\partial u}{\partial z}+v \frac{\partial u}{\partial r}\right)=-\frac{\partial p}{\partial z}+2 \frac{\partial}{\partial z}\left(\mu \frac{\partial u}{\partial z}\right)+ \\
& \frac{1}{r} \frac{\partial}{\partial r}\left[\mu r\left(\frac{\partial u}{\partial r}+\frac{\partial v}{\partial z}\right)\right]+F_{z}+\rho g
\end{aligned}
$$

: 반경 $(r)$ 방향

$$
\begin{array}{r}
\rho\left(u \frac{\partial v}{\partial z}+v \frac{\partial v}{\partial r}\right)=-\frac{\partial p}{\partial r}+\frac{2}{r} \frac{\partial}{\partial r}\left(\mu r \frac{\partial v}{\partial r}\right)-\frac{2 \mu v}{r^{2}}+ \\
\frac{\rho w^{2}}{r}+\frac{1}{r} \frac{\partial}{\partial z}\left[\mu r\left(\frac{\partial u}{\partial r}+\frac{\partial v}{\partial z}\right)\right]+F_{r}
\end{array}
$$

: 회전 $(\theta)$ 방향

$$
\begin{aligned}
\rho\left(u \frac{\partial w}{\partial z}+v \frac{\partial w}{\partial r}\right) & =\frac{\partial}{\partial z}\left(\mu \frac{\partial w}{\partial z}\right)+\frac{1}{r} \frac{\partial}{\partial r}\left(\mu r \frac{\partial w}{\partial r}\right) \\
& -\frac{w}{r}\left(\rho v+\frac{\mu}{r}+\frac{\partial \mu}{\partial r}\right)
\end{aligned}
$$

위와 같이 묘사된, 운동량 보존 방정식에서 $p$ 는 압력, $w$ 는 회전방향의 플라즈마 속도이고 $g$ 는 중력가속도, $\mu$ 는 점성계수를 나타낸다. $F_{z}$ 와 $F_{r}$ 은 축방향 및 반경방향으로 작용하는 로렌쯔 (Lorentz) 힘으로서 각각 아래 식 (21)과 (22)로 표현될 수 있다.

$$
\begin{aligned}
& F_{z}=-\frac{1}{2} \sigma \operatorname{Re}\left[E_{\theta} B_{r}^{*}\right] \\
& F_{r}=+\frac{1}{2} \sigma \operatorname{Re}\left[E_{\theta} B_{z}^{*}\right]
\end{aligned}
$$

위 식에서 $B_{r}^{*}$ 및 $B_{z}^{*}$ 는 각각 반경방향 및 축방 향 자기장 성분의 복소공액에 해당한다.

(3) 에너지 보존방정식

$$
\begin{aligned}
\rho\left(u \frac{\partial h}{\partial z}+v \frac{\partial h}{\partial r}\right) & =\frac{\partial}{\partial z}\left(\frac{k}{C_{p}} \frac{\partial h}{\partial z}\right)+\frac{1}{r} \frac{\partial}{\partial r}\left(r \frac{k}{C_{p}} \frac{\partial h}{\partial r}\right) \\
& +P_{j}-R^{0}
\end{aligned}
$$

식 (23)에서 $h, \kappa, C_{p}$ 는 각각 플라즈마 엔탈피, 열전도 계수, 비열용량을 나타내며 $P_{j}$ 는 주울 열 발생을 $R^{0}$ 는 복사열손실을 의미하는 것으로 이 중 단위체적 당 주울 열 발생 $P_{j}$ 는 플라즈마 내 에 유기된 전기장 $E_{\theta}$ 및 그 복소공액 $E_{\theta}^{*}$ 의 곱으 로 아래 식 (24)와 같이 주어진다.

$$
P_{j}=\frac{1}{2} \sigma \operatorname{Re}\left[E_{\theta} E_{\theta}^{*}\right]
$$

각 식들에 포함된 비열용량 전기전도도 및 기타
수송계수들은 수치 계산 시 모두 참고문헌 [8]의 부록에 제시된 $\mathrm{Ar}$ 기체에 대한 값들을 온도에 대해 보간하여 사용하였다.

(4) 자기벡터 포텐샬 방정식

한편 자기벡터포텐샬 $A$ 가 회전방향성분 $A_{\theta}$ 만 가진다고 가정하면 가둠관 내 전자기장 분포는 아래 식 (25)와 (26)과 같이 표현될 수 있다.

$$
\begin{aligned}
& \frac{1}{r} \frac{\partial}{\partial r}\left(r \frac{\partial A_{R}}{\partial r}\right)+\frac{\partial^{2} A_{R}}{\partial z^{2}}-\frac{A_{R}}{r^{2}}+\mu_{0} \omega \sigma A_{I}=0 \\
& \frac{1}{r} \frac{\partial}{\partial r}\left(r \frac{\partial A_{I}}{\partial r}\right)+\frac{\partial^{2} A_{I}}{\partial z^{2}}-\frac{A_{I}}{r^{2}}-\mu_{0} \omega \sigma A_{R}=0
\end{aligned}
$$

위 식에서 $A_{R}$ 과 $A_{I}$ 는 $A_{\theta}$ 의 실수부와 허수부를 표현하며 맥스웰(Maxwell) 방정식에 따라 전기장 의 회전방향 성분 $E_{\theta}$, 자기장 세기의 반지름방향 성분 $H_{r}$ 및 축방향 성분 $H_{z}$ 에 대해 아래와 같은 관계식을 가진다.

$$
\begin{aligned}
& E_{\theta}=-j \omega A_{\theta} \\
& H_{r}=-\frac{1}{\mu_{0}} \frac{\partial A_{\theta}}{\partial z} \\
& \mu_{0} H_{z}=\frac{1}{r} \frac{\partial\left(r A_{\theta}\right)}{\partial r}
\end{aligned}
$$

Table 2. Boundary conditions for mass, momentum and energy conservation equations

at the RF torch inlet $(\mathrm{z}=0)$

$0 \leq r \leq R_{1}: u=\frac{Q_{1}}{\pi R_{1}^{2}}, v=w=0, T=350 \mathrm{~K}$,

$R_{2} \leq r \leq R_{3}: u=\frac{Q_{2}}{\pi\left(R_{3}^{2}-R_{2}^{2}\right)}, v=w=0, \quad T=350 \mathrm{~K}$

$R_{4} \leq r \leq R \quad: u=\frac{Q_{3}}{\pi\left(R^{2}-R_{4}^{2}\right)}, v=w=0, \quad T=350 \mathrm{~K}$

$0 \leq r \leq R: \frac{\partial A_{R}}{\partial z}=\frac{\partial A_{I}}{\partial z}=0$

at the centerline $(r=0)$

$\frac{\partial u}{\partial r}=\frac{\partial h}{\partial r}=v=w=A_{R}=A_{I}=0$

at the RF torch exit $\left(\mathrm{z}=L_{0}\right)$

$\frac{\partial(\rho u)}{\partial z}=\frac{\partial v}{\partial z}=\frac{\partial w}{\partial z}=\frac{\partial h}{\partial z}=\frac{\partial A_{R}}{\partial z}=\frac{\partial A_{I}}{\partial z}=0$

at the confinement tube wall $\left(r=R_{0}\right)$

$u=v=w=0, \quad T=350 \mathrm{~K}$ 
이로부터 식 (21), (22) 및 (24)로 주어졌던 플라 즈마 내 단위체적 당 작용하는 로렌쯔 힘 $F_{z}$ 와 $F_{r}$ 및 주울열 발생 $P_{j}$ 가 계산된다.

\subsubsection{3 경계 조건}

앞에서 기술한 질량, 운동량 및 에너지 방정식 에 대한 경계조건과 가둠관 벽면 $(r=R)$ 에서의 것 을 제외한 자기벡터 포텐샬 방정식에 대한 경계 조건을 Table 2에 정리하여 나타내었다.

한편 자기유체역학 수치해석 결과로부터 등가 저 항과 등가 인덕턴스를 계산하는 방법을 소개하기 위해 가둠관 벽면 $(r=R)$ 에서의 전자기장 방정식 과 관련된 경계조건을 별도 기술하고자 한다.

벽면에서 벡터 포텐샬의 실수부 $A_{R}$ 와 허수부 $A_{I}$ 는 고주파 코일 전류와 유도 플라즈마 전류에 의해 다음과 같이 결정된다[10].

$$
\begin{aligned}
\left.A_{R}\right)_{r=R} & =\frac{\mu_{0}}{2 \pi}\left[\sum_{l}\left(\frac{R_{c l}}{R}\right)^{1 / 2} G\left(k_{l}\right) I_{l}\right. \\
& \left.+\sum_{j} \omega \sigma_{i j} S_{i j} A_{I i j}\left(\frac{r_{j}}{R}\right)^{1 / 2} G\left(k_{i j}\right)\right] \\
\left.A_{I}\right)_{r=R} & =-\frac{\mu_{0}}{2 \pi}\left[\sum_{i} \sum_{j} \omega \sigma_{i j} S_{i j} A_{R i j}\left(\frac{r_{j}}{R}\right)^{1 / 2} G\left(k_{i j}\right)\right]
\end{aligned}
$$

여기서 $k_{l}, k_{i j}$ 및 $G(k)$ 는 아래 식과 같다.

$$
\begin{aligned}
& k_{l}=\left[\frac{4 R R_{c l}}{\left(z_{w}-z_{c l}\right)^{1 / 2}+\left(R+R_{c l}\right)^{1 / 2}}\right]^{1 / 2} \\
& k_{i j}=\left[\frac{4 R r_{j}}{\left(z_{w}-z_{i}\right)^{1 / 2}+\left(R+r_{j}\right)^{1 / 2}}\right]^{1 / 2} \\
& G(k)=\frac{\left(2-k^{2}\right) K(k)-2 E(k)}{k}
\end{aligned}
$$

위 식에서 $I_{l}$ 은 $l$ 번째 코일에 흐르는 전류 $R_{c l}$ 과 $z_{c l}$ 은 각각 중심축과 입구로부터 떨어진 $l$ 번 째 코일의 반지름 및 축 방향 거리를 표시하는 값이며 $S_{i j}$ 는 $(i, j)$ 셀의 면적을 $K(k)$ 와 $E(k)$ 는 완전타원적분(the complete elliptic integrals) 을 나타낸다. 플라즈마 출력 $P_{0}$ 는 식 $(24)$ 의 단위 체적당 발생하는 주울 열 $P_{j}$ 를 플라즈마 가둠관 내부 전체에 대해 식 (35)와 같이 적분하여 구한 다.

$$
P_{0}=\frac{1}{2} \int_{\text {plasma }} \rho E_{\theta}^{2} \mathrm{~d} v
$$

또한 총 이용가능한 자기에너지 $P_{m a q}$ 는 식 (36) 과 같이 자기장 세기 $H$ 의 분포를 Fig. 4 의 가둠 관과 코일 사이 영역을 포함하여 전 영역에 걸쳐 적분함으로써 계산할 수 있다.

$$
P_{\text {mag }}=\frac{1}{2} \pi f \mu_{0} \int_{v}\left(H_{r}^{2}+H_{z}^{2}\right) \mathrm{d} v
$$

여기서 $H_{r}$ 과 $H_{z}$ 은 각각 자기장 세기의 반지름 방향 성분과 축방향 성분이며 가둠관 내 플라즈 마 영역에서 $H_{r}$ 과 $H_{z}$ 은 식 (28)과 (29)에 따라 플라즈마 내 자기벡터포텐샬 $A_{\theta}$ 로부터 계산된다. 한편 $P_{m a g}$ 계산에 필요한 가둠관과 코일 사이 영역의 자기벡터포텐샬 $A_{\theta}$ 분포는 계산이 끝난 후 코일 전류에 의한 기여와 플라즈마 전류에 의 한 기여의 선형 결합을 통해 식 (37) 및 식 (38) 과 같이 구할 수 있다[11].

$$
\begin{aligned}
A_{R . i}= & \frac{\mu_{0} I_{0}}{2 \pi} \sqrt{\frac{R_{c}}{r}} \sum_{i=1}^{c o i l} G\left(k_{i}\right) \\
& +\frac{\mu_{0} \omega}{2 \pi} \sum_{i=1}^{C . V} \sqrt{\frac{r_{i}}{r}} \sigma_{i} A_{I . i} S_{i} G\left(k_{i}\right) \\
A_{I . i}= & \frac{\mu_{0} \omega}{2 \pi} \sum_{i=1}^{C . V .} \sqrt{\frac{r_{i}}{r}} \sigma_{i} A_{R . i} S_{i} G\left(k_{i}\right)
\end{aligned}
$$

여기서 $r$ 은 $R<r<R_{c}$ 사이의 영역을 가리킨 다. 수치계산 과정은 먼저 계산 수렴된 열유동장 에서 자기벡터포텐샬 $A_{\theta}$ 를 반복계산하고 수렴된 $A_{\theta}$ 값으로부터 전자기 변수값 및 해당경계조건 들을 모두 계산한 뒤 입력된 플라즈마 출력 $P_{0}=$ $10 \mathrm{~kW}$ 여부를 판단한다. 판단결과에 따라 해당 출력이 만족될 때까지 플라즈마 전류 $I_{0}$ 를 변화 시켜 가면서 열유동장 계산 등 위 과정을 반복 수행하여 진행하였다. 마지막으로 최종 결과값으 로부터 계산된 $P_{0}, P_{m a g}$ 및 코일 전류 $I_{0}$ 를 식 (12), (13) 및 (14)에 대입함으로써 코일 양단에서 걸리는 등가 인덕턴스 $L_{e q}$, 등가 플라즈마 저항 $R_{e q}$ 및 결합효율 $\eta_{c}$ 를 구하였다.

\section{2 결과 및 토론}

\subsection{1 고주파(RF) 주파수의 영향}

$\mathrm{RF}$ 주파수 $f$ 가 유도결합 플라즈마의 전기적 특성에 미치는 영향을 살펴보기 위하여 가둠관 반지름 $R=20 \mathrm{~mm}$ 일 때 $1 \mathrm{MHz}$ 와 $6 \mathrm{MHz}$ 인 경우에 대해 해석해와 수치해석으로부터 얻은 회 전방향 전기장 $E_{\theta}$ 의 반지름방향 분포를 Fig. 5에 
나타내었다. Fig. 5 및 이하 결과 그림에서 표시 되는 반경방향 물성 분포 결과는 첫 번째와 두 번째 코일 가운데 지점인 $\mathrm{z}=45 \mathrm{~mm}$ 인 곳에서 반지름방향을 따라 추출된 데이터를 사용한 것이 다. 이 외 계산에 사용된 토치 설계변수 조건은 $N=4$ 회, $l=66 \mathrm{~mm}$ 이며 운전조건은 Table 1과 같다.

먼저 Fig. 5의 해석해 결과에서 $f=1 \mathrm{MHz}$ 에 비해 $f=6 \mathrm{MHz}$ 일 때 표피효과에 의해 플라즈 마 반지름 $r_{0}$ 에 대응하는 최대 $E_{\theta}$ 값이 가둠관 벽쪽으로 치우쳐서 더 크게 나타나는 반면 중심 축 쪽으로는 더 빠르게 감소하는 현상이 나타남 을 관찰 수 있다. 곧 주파수가 커지면 표피깊이 가 작아져 $E_{\theta}$ 는 중심축 방향으로 급격히 감쇠하 게 되지만 상대적으로 좁은 표피깊이 내에서 $P_{0}$ $=10 \mathrm{~kW}$ 를 유지하기 위해 더 많은 양의 플라즈 마 전류가 유기되어야 하므로 최대전기장이 증가 하게 된다. 따라서 주파수가 증가함에 따라 Fig. 6과 같이 등가 저항 $R_{e q}$ 도 함께 증가하게 된다.

또한 원통형 전도체 모형의 가정에 따라 플라 즈마 반지름 $r_{0}$ 에서 열전도를 통해 가둠관 쪽으 로 빠져나가는 열량과 좁은 표피깊이 내에서 와 전류에 의해 발생하는 주울 열이 균형을 이루려 면 주파수가 높을수록 플라즈마 반지름 $r_{0}$ 는 증 가하게 된다. 플라즈마 반지름 $r_{0}$ 의 증가는 가둠 관과 플라즈마 사이의 누설 자속을 줄이고 플라 즈마를 관통하는 자속의 양을 늘리는 효과를 가 져와 플라즈마 인덕턴스를 높이고 등가 인덕턴스 $L_{e q}$ 를 감소시키는 효과가 있을 것이라 생각된

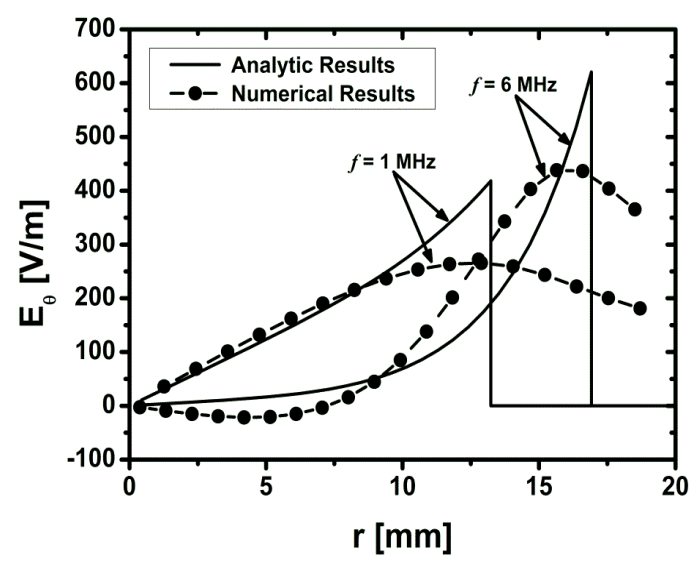

Fig. 5. Radial profiles of $E_{\theta}$ for two different frequencies of $f=1$ and $6 \mathrm{MHz}$
다. 그러나 가둠관 반지름이 고정되어 있으면 주 파수 증가에 의한 플라즈마 반지름의 증가에는 한계가 있으므로 등가 인덕턴스는 Fig. 6과 같이 주파수가 커질수록 천천히 감소하게 된다.

한편 Fig. 5에서 수치해석 결과의 경우 유동에 의한 플라즈마 모양 변형에도 불구하고 최대전기 장이 해석해로부터 얻은 플라즈마 반지름 $r_{0}$ 근 처에서 형성되고 주파수가 커짐에 따라 $E_{\theta}$ 의 반 지름방향 분포도 해석해의 경우와 비슷하게 중심 축을 향해 급격히 감쇠함을 보여주고 있다. 그러 나 수치해석 결과는 플라즈마 반지름과 가둠관 사이의 영역에서도 와전류를 유기시키는 $E_{\theta}$ 가 존재하고 이에 따라 주울 열 발생이 일어나므로 원통형 플라즈마와 비교하여 고온 영역이 반지름 방향으로 더 팽창한 플라즈마가 얻어진다. 이에 따라 플라즈마를 관통하는 자속도 해석해와 비교 하여 더 많아지므로 최대 전기장 값은 줄어드는 (Fig. 5 비교) 대신 등가 플라즈마 저항과 등가 인덕턴스는 더 작게 계산된다.

한편 플라즈마 출력 $P_{0}$ 가 $10 \mathrm{~kW}$ 로 일정할 때 주파수 증가에 따른 등가 저항 $R_{e q}$ 의 증가는 식 (13)에 따라 코일 전류 $I_{0}$ 의 감소를 가져오며, 코 일전류의 감소는 다시 식 (7)에 의해 출력 유지 에 필요한 플라즈마 반지름 $r_{0}$ 에서의 자기장 세 기 $H_{0}$ 를 감소시킨다. 이와 같은 주파수 변화에 따른 자기장 세기 $H_{0}$ 의 변화는 Fig. 7에 도시한 가둠관 내 축방향 자기장 $B_{z}$ 의 반지름방향 분포 로부터 확인할 수 있다.

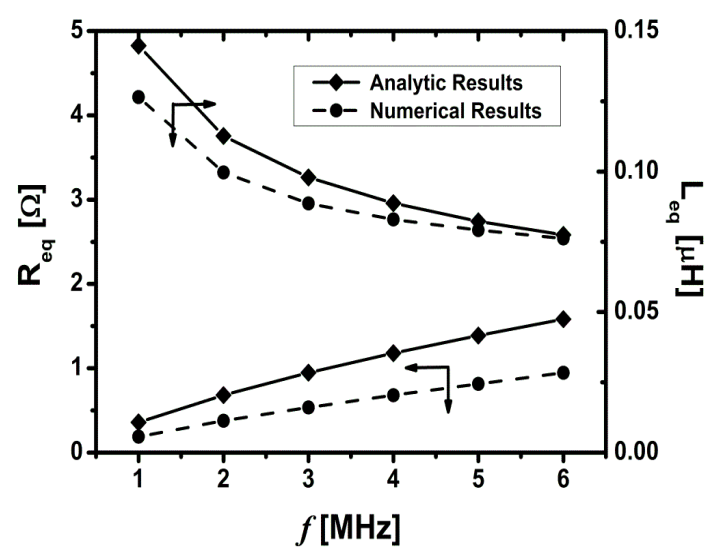

Fig. 6. Analytic and numerical results for $R_{e q}$ and $L_{e q}$ according to frequency $f\left(P_{0}=10 \mathrm{~kW}, R=20 \mathrm{~mm}, N=4\right)$ 


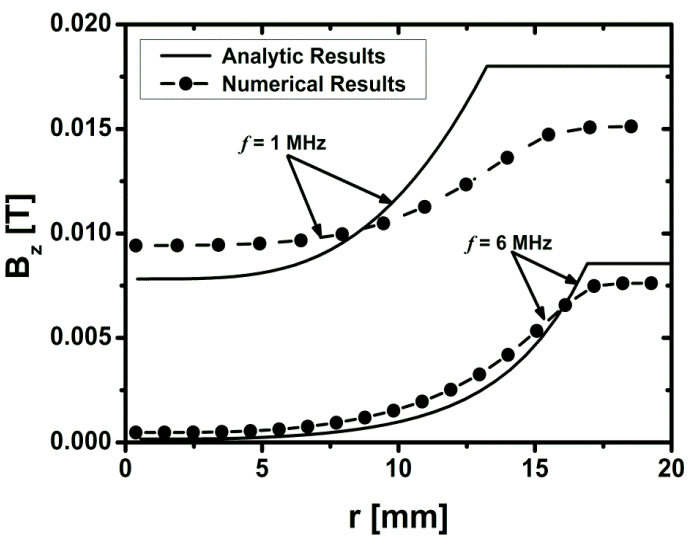

Fig. 7. Radial profiles of $B_{z}$ for two different frequencies of $f=1$ and $6 \mathrm{MHz}\left(P_{0}=10 \mathrm{~kW}, R=20 \mathrm{~mm}\right.$, $N=4)$

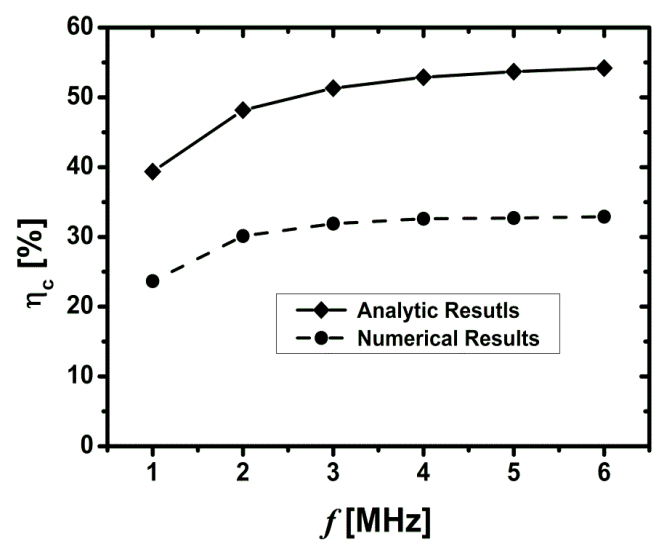

Fig. 8. Analytic and numerical results for coupling efficiency, $\eta_{c}$ according to frequency, $f\left(P_{0}=10\right.$ $\mathrm{kW}, R=20 \mathrm{~mm}, N=4$ )

Figure 7에서 플라즈마 내 축방향 자기장 $B_{z}$ 및 해석해 결과의 플라즈마 반지름 $r_{0}$ 에 대응하 는 자기장 세기 $H_{0} \quad\left(=B_{z}\left(r_{0}\right) / \mu_{0}\right)$ 는 $f=1 \mathrm{MHz}$ 일 때, 더 높게 나타난다. 곧 낮은 주파수에서는 플라즈마 반지름이 작아지므로 플라즈마와 가둠 관 사이의 누설 자속이 커져 출력유지에 필요한 자기장 세기 $H_{0}$ 가 증가하는 반면 표피깊이는 상 대적으로 넓어지므로 플라즈마 중심축까지 축방 향 자기장 $B_{z}$ 이 충분히 감쇠되지 않고 분포하게 된다. 따라서 일정출력 $\left(P_{0}=10 \mathrm{~kW}\right)$ 을 유지하기 위한 기자력 $\left(N I_{0}\right)$ 과 토치 내 총 이용가능한 자기
에너지 $P_{m a g}$ 는 주파수가 감소할수록 증가하게 되므로 이 두 변수의 비를 나타내는 결합효율 $\eta_{c}$ 는 Fig. 8과 같이 떨어지게 된다.

\subsection{2 가둠관 반지름의 영향}

가둠관 반지름 $R$ 이 유도결합 플라즈마의 전기 적 특성에 미치는 영향을 살펴보기 위하여 $R=$ $15 \mathrm{~mm}, 25 \mathrm{~mm}, 35 \mathrm{~mm}$ 인 경우에 대해 해석해와 수치해석으로부터 얻은 회전방향 전기장 $E_{\theta}$ 의 반지름방향 분포를 Fig. 9에 나타내었다. Fig. 9 에서 수치해석 결과는 첫 번째와 두 번째 코일 가운데 지점인 $\mathrm{z}=45 \mathrm{~mm}$ 인 곳의 반지름방향 분 포이다. 가둠관 반지름 이 외 계산에 사용된 토 치 설계변수 조건은 Table 1과 같다. 먼저 Fig. 9 의 해석해 결과로부터 가둠관 반지름 $R$ 이 커질 수록 회전방향 전기장 $E_{\theta}$ 가 최대가 되는 지점인 플라즈마 반지름 $\left(r_{0}\right)$ 이 거의 비례해서 증가함을 알 수 있다. 또한 최대전기장은 가둠관 반지름이 증가할수록 감소하는 반면 주파수가 고정되어 있 으므로 중심축 방향으로의 감소정도와 관계있는 표피깊이는 거의 변하지 않음을 관찰할 수 있다. 덧붙여 가둠관과 플라즈마 사이의 간격 $R-r_{0}$ 는 각각 $R=15,25,35 \mathrm{~mm}$ 일 때, $3.4,3.8,4.3 \mathrm{~mm}$ 로 계산되어 가둠관 반지름이 증가함에 따라 조금씩 증가하므로 이 공간을 지나는 누설 자속이 늘어 날 뿐 아니라 가둠관 반지름과 함께 코일 반지름 도 늘어나야하므로 등가 인덕턴스 $L_{e q}$ 는 Fig. 10 에 나타낸 바와 같이 가둠관 반지름이 증가함에 따라 증가하게 된다.

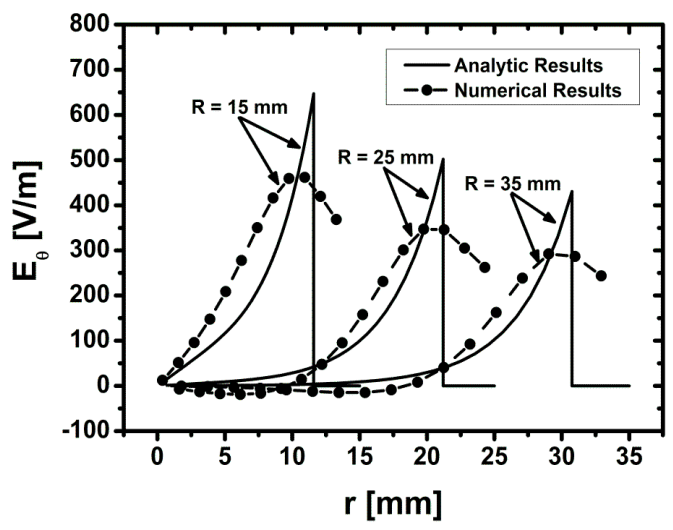

Fig. 9. Radial profiles of $E_{\theta}$ for different confinement tube radius of $R=15$, 25 and $35 \mathrm{~mm}$ (Solid and dotted lines correspond to the analytic and numercial resutls, respectively) 


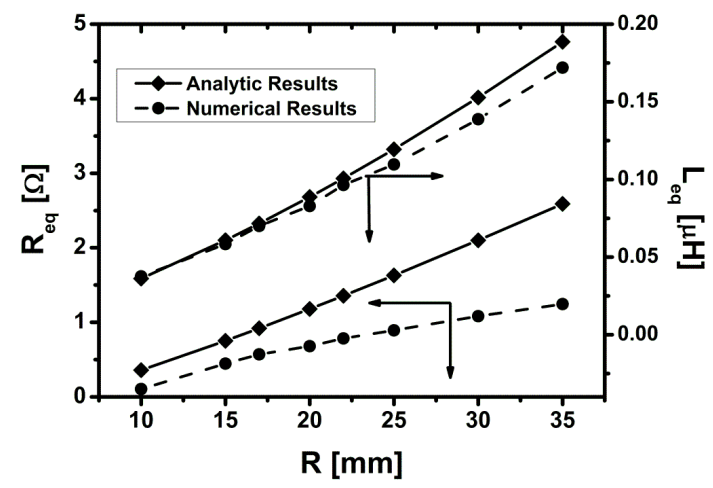

Fig. 10. Analytic and numerical results for $R_{e q}$ and $L_{e q}$ according to confinement tube radius, $R\left(P_{0}=10\right.$ $\mathrm{kW}, f=4 \mathrm{MHz}, N=4)$

한편 수치해석 결과 역시 최대전기장은 해석 해로부터 얻은 플라즈마 반지름 $r_{0}$ 근처에서 형 성되므로 플라즈마의 고온 영역이 가둠관 반지름 $R$ 이 증가할수록 확장된다는 것을 알 수 있다. 그러나 원통형 전도체 모형을 쓴 해석해와는 달 리 가둠관과 플라즈마 사이의 영역에서도 전기장 이 넓게 분포하게 되며 가둠관과 플라즈마 사이 의 간격 $R-r_{0}$ 는 가둠관 반지름 $R$ 이 커질수록 증가하므로 Fig. 10에 나타난 바와 같이 해석해 와 비교하여 등가 저항 $R_{e q}$ 는 천천히 증가한다.

또한 축방향 자기장 $B_{z}$ 의 반지름방향 분포를 나타낸 Fig. 11의 해석해 결과로부터 가둠관 반 지름 $R$ 이 증가할수록 플라즈마 내 축방향 자기 장 $B_{z}$ 의 크기와 플라즈마 반지름 


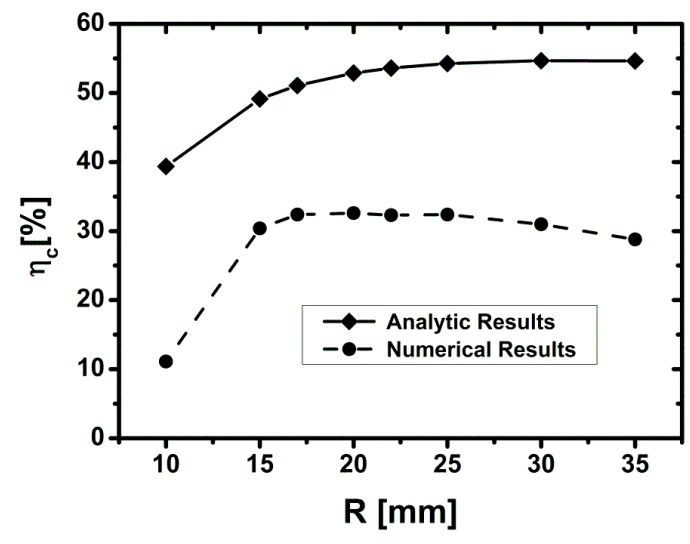

Fig. 12. Analytic and numerical results for coupling efficiency, $\eta_{c}$ according to confinement tube radius, $R\left(P_{0}=10\right.$ $\mathrm{kW}, f=4 \mathrm{MHz}, N=4$ )

\subsection{3 코일 감은수의 영향}

식 (7) 및 식 (9)에서 나타낸 자기장 세기 $H_{0}$ 와 코일 감은수 $N$ 과의 관계로부터 코일 감은수 가 늘어나면 $H_{0}$ 는 항상 감소한다. 따라서 코일 감은수의 증감을 통해 효율적인 에너지 전달을 고려해 볼 수 있다. 이러한 코일 감은수가 고주 파 유도결합 플라즈마 토치의 결합효율에 미치는 영향을 살펴보기 위해 가둠관 반지름 $R=20$ $\mathrm{mm}$, 주파수 $f=4 \mathrm{MHz}, d_{c}=15 \mathrm{~mm}$ 일 때, $N=$ 3 회에서 $N=5$ 회 사이의 경우에 대해 해석해와 수치해석으로부터 얻은 결과를 Fig. 13에서 Fig. 16 까지 도시하였다.

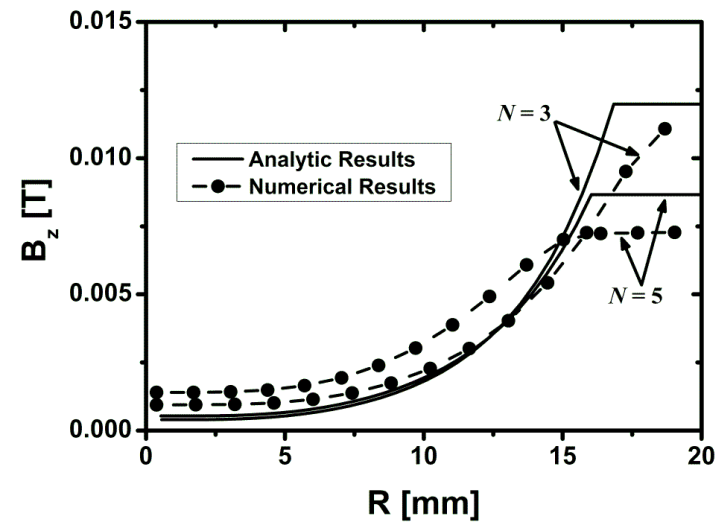

Fig. 13. Radial profiles of $B_{z}$ for different coil turn numbers of $N=3$ and 5 (Solid and dotted lines correspond to the analytic and numercial resutls, respectively)
먼저 축방향 자기장 $B_{z}$ 의 반지름방향 분포를 도시한 Fig. 13으로부터 코일 감은수가 증가하면 플라즈마 길이가 길어져서 일정출력 $10 \mathrm{~kW}$ 유 지를 위해 플라즈마 반지름 


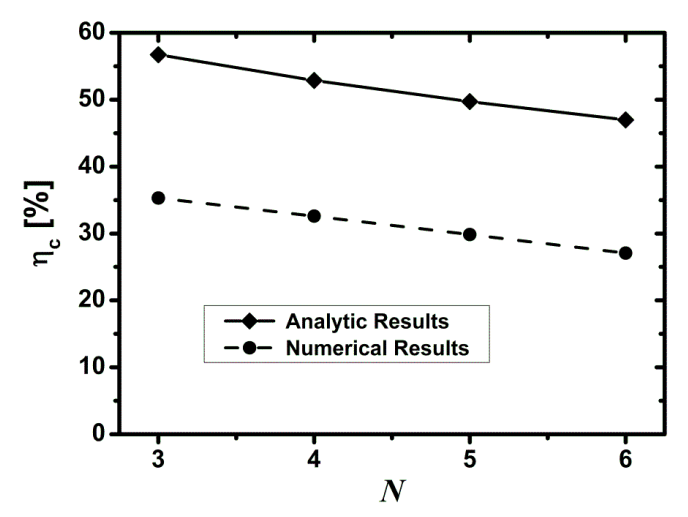

Fig. 16. Analytic and numerical calculation results for coupling efficiency, $\eta_{c}$ according to the coil turn numbers, $N\left(R=20 \mathrm{~mm}, P_{0}=10 \mathrm{~kW}, f=4\right.$ $\left.\mathrm{MHz}, d_{c}=15 \mathrm{~mm}\right)$

비례해서 증가하므로 등가 인덕턴스 $L_{e q}$ 는 Fig. 15 와 같이 등가저항 $R_{e q}$ 보다 더 크게 증가하게 된다.

따라서 식 (16)에 따라 결합효율 $\eta_{c}$ 의 경우 Fig. 16과 같이 해석해와 수치해석 모두 코일 감 은수가 증가할수록 감소하는 것으로 나타난다. 반면 코일 감은수의 증가는 유도코일 전류의 감 소와 코일 길이 및 이에 따른 플라즈마 길이의 증가를 가져다주므로 대출력 고주파 유도결합 플 라즈마 토치 설계 시 지나친 코일 전류 증가와 급격한 가둠관으로의 열유속 증가를 피하기 위해 서는 플라즈마 출력에 비례하여 코일 감은수를 선택적으로 늘이는 설계가 필요하다.

\subsection{4. $10 \mathrm{~kW}$ 급 고주파 유도결합플라즈마 토치 의 최적 설계 변수 범위 및 열유동장}

이상의 결과를 바탕으로 $10 \mathrm{~kW}$ 급 고주파 유 도결합플라즈마 토치에 대해 결합효율을 극대화 하는 최적의 주파수 가둠관 및 코일 감은수의 범 위를 각각 $f=4 \sim 6 \mathrm{MHz}, R=17 \sim 25 \mathrm{~mm}$ 및 $N$ $=3 \sim 4$ 로 추정할 수 있다. 결합효율의 극대화로 인하여 이 범위에서 설계된 고주파 유도결합 플 라즈마 토치는 고주파 전원에서 임피던스 정합에 대한 부담을 최소화 할 수 있다. 또한 $10 \mathrm{~kW}$ 출 력 범위에서는 유도코일을 통해 인가되는 전자기 장이 표피깊이 내에서 대부분 소진되고 플라즈마 중심 영역에서는 거의 존재하지 않는 반면 빠른 열전달을 통해 플라즈마의 고온상태를 쉽게 유지 할 수 있기 때문에 중심축을 따라 탐침을 삽입하
거나 물질을 주입하는 등 중심부의 고온 영역 응 용에 유리하다. Fig. 17은 제시된 최적설계범위 중 $f=4 \mathrm{MHz}, R=20 \mathrm{~mm}, d_{c}=15 \mathrm{~mm}$ 및 $N=3$ 일 때 Table 1에 따라 계산된 유도결합플라즈마 의 온도장과 속도장을 묘사한 것이다. Fig. 17로 부터 제시된 설계조건에서 발생된 유도결합 플라 즈마는 코일 영역에서 $8000 \mathrm{~K}$ 이상의 고온 불꽃 을 형성하고 있으며 표피깊이에서의 주울 열 가 열로 인해 최고 온도 영역이 중심축에서 벗어나 있으나, 플라즈마 내 열전달을 통해 중심축의 온 도 역시 $10,000 \mathrm{~K}$ 이상이 될 것을 예측할 수 있 다. 가둠관 반지름의 경우 너무 크면 플라즈마 중심영역으로의 열전달이 상대적으로 떨어질 수 있으며 반대로 너무 작으면 가둠과 쪽으로의 열 손실이 급격히 증가하여 열효율이 떨어진다. 코 일 감은수 역시 너무 많으면 주어진 출력대비 플 라즈마가 길어지고 가둠관 벽 쪽으로의 열 손실 및 누설 자속이 증가할 것이지만 Fig. 17의 3회 의 경우 대부분의 자속은 짧은 경로를 통해 코일 영역 내부에 형성된 고온 플라즈마 영역을 지나 가게 된다. 마지막으로 Fig. 17 (b)의 속도장 분 포 그림으로부터 코일 상부에 유도결합 플라즈마 특유의 재순환 역류가 존재함을 알 수 있으며 이 와 같은 유동 특성은 유도결합 플라즈마 응용 시 설계변수 해석과는 별도로 제어해야할 부분이 된 다.

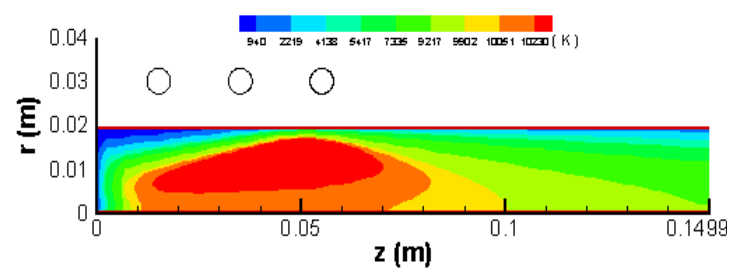

(a)

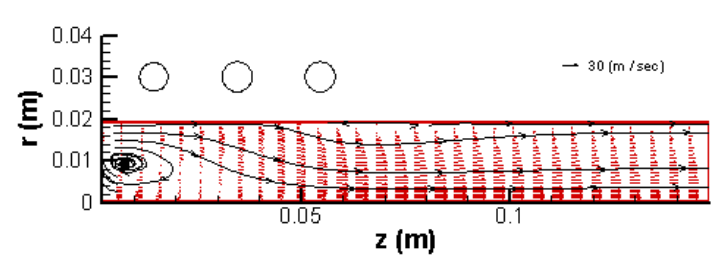

(b)

Fig. 17. Calculation results of temperature (a) and velocity (b) fields generated by inductively coupled plasma torch with $f=4 \mathrm{MHz}, R=$ $20 \mathrm{~mm}, d_{c}=15 \mathrm{~mm}$ and $N=3$ 


\section{III. 결 론}

$10 \mathrm{~kW}$ 급 고주파 유도결합 플라즈마 토치를 대상으로 하여, $\mathrm{RF}$ 주파수, 가둠관 반지름 및 코 일 감은수 변화에 따른 등가 저항 $R_{e q}$ 등가 인 덕턴스 $L_{e q}$ 및 결합효율 $\eta_{c}$ 등의 변화를 해석해 및 수치해석을 이용하여 계산하고 그 결과를 상 호 비교하면서 추적하였다. 계산 결과 등가저항 $R_{e q}$ 는 $\mathrm{RF}$ 주파수 가둠관 반지름 및 코일 감은수 가 증가함에 따라 커지며 등가 인덕턴스 $L_{e q}$ 는 주파수가 증가할수록 작아지는 반면 가둠관 반지 름과 코일 감은수의 증가에 따라 커지는 경향이 있음을 파악하였다. 등가 저항 $R_{e q}$ 와 등가 인덕 턴스 $L_{e q}$ 의 이러한 거동에 대한 관찰을 바탕으로 $10 \mathrm{~kW}$ 급 고주파 유도결합 플라즈마 토치에 대 해 식 (16)과 같이 $R_{e q}$ 에 대한 $L_{e q}$ 의 비로 주어 지는 결합효율을 극대화하는 최적의 주파수 가둠 관 및 코일 감은수의 범위를 각각 $f=4 \sim 6 \mathrm{MHz}$, $R=17 \sim 25 \mathrm{~mm}$ 및 $N=3 \sim 4$ 로 추정할 수 있었다. 특히 주어진 출력에 대해 주파수 가둠관 반지름 및 코일 감은수와 같은 설계변수의 최적 범위를 찾아내기 위해 해석적 방법으로 도입한 원통형 전도체 모델은 유동을 고려한 수치해석 결과와 비교하여 유사한 범위의 값을 상대적으로 빠르고 손쉽게 제공해 주었다. 그러나 결과적으로 계산 된 결합효율 값은 해석해와 비교하여 상대적으로 더 높게 나타났는데 이러한 계산 값의 차이는 원 통형 고체 상태가 아닌 플라즈마 유동 흐름에 기 인한 표피깊이의 변형과 반경방향 확산 때문인 것으로 파악되었다. 곧 플라즈마 유동은 인가된 고주파 전자기 에너지를 흡수하기 위해 원통형 전도체와 비교하여 반경방향 및 축방향으로 더 넓게 퍼질 수 있으므로 고주파 전원 입력단에서 낮은 등가 저항과 높은 등가 인덕턴스를 유발한 다고 생각된다. 이러한 차이는 이온화된 열유체 상태의 플라즈마를 발생 유지시키기 위한 플라즈 마 토치 및 고주파 시스템 설계가 일반적인 전도 체 유도가열 장치와 비교하여 더 큰 등가 인덕턴 스와 낮은 등가 저항값을 가진 회로에 대해 수행 되어야 함을 의미한다.

유도결합 플라즈마는 플라즈마 발생 및 유지 원리 상 핵심 설계변수 간 상호복잡한 의존 관계 를 피할 수 없다 하더라도 주어진 출력에 대해 최적의 주파수와 가둠관 반지름 범위가 존재하므 로 본 논문에서 소개한 해석적 방법 및 수치해석 방법을 통해 출력조건에 따라 높은 결합 효율을 보이는 주파수 및 가둠관 범위를 찾을 경우 응용
목적에 맞는 최적의 고주파 플라즈마 토치 시스 템을 설계할 수 있을 것이라 여겨진다. 특히 우 주 추진체 및 초음속 플라즈마 풍동용 대출력 고 주파 유도결합 플라즈마 토치 설계 시 지나친 코 일 전류 증가와 급격한 가둠관으로의 열유속 증 가를 피하기 위해서는 최적의 주파수 및 가둠관 반지름 조건에서 플라즈마 출력에 비례하여 코일 감은수를 선택적으로 늘리는 설계도 필요하리라 여겨진다.

\section{참고문헌}

1) Marieu, V., Reynier, Ph., Marraffa, L., Filippisa, F., and Caristia, C., "Evaluation of SCIROCCO plasma wind-tunnel capabilities for entry simulations in CO2 atmospheres", Acta Astronaut., Vol. 61, 2007, pp.604 616.

2) Takahashi, Y., Kihara, h., and Abe, K., "Numerical Investigation of Nonequilibrium Plasma Flows in Constrictor- and SegmentedType Arc Heaters," J. Thermophys. Heat Transfer, Vol. 24(1), 2010, pp.31 39.

3) Herdrich, G., Auweter-Kurtz M., and Kurtz. H. L.., "New Inductively Heated Plasma Source for Reentry Simulations," J. Thermophys. Heat Transfer, Vol. 14(2), 2000, pp.244 249.

4) Funaki, I., Kubota, K., Okuno, Y., Sato, H., Fujino, T., "Numerical study of low-power $\mathrm{MPD}$ arcjet," 한국추진공학회 2008년 영문 학술 대회 논문집, Mar. 2008, pp.570-573

5) 신재렬, 이대성, 오세종, 최정열, "하이드 라진 아크젯 추력기의 수치적 모델링," 한국항 공우주학회지, 제36권 제9호, 2008, pp.907-915

6) Freeman, M.P., and Chase, J.D., "Energy transfer mechanism and typical operating characteristics for the thermal rf plasma generator", J. Appl. Phys., Vol. 39, 1968, pp.180 190.

7) Merkhouf, A., and Boulos, M.I., "Integrated model for the radio frequency induction plasma torch and power supply system", Plasma Sources Sci. Technol. Vol. 7, 1998, pp.599-606.

8) Boulos, M.I., Fauchais, P., Pfender, E., "Thermal Plasmas : Fundamentals and Applications Volume I", Plenum Press, 1994. 
9) Raizer. Y. P., "Gas Discharge Physics", Springer-Verlag, 1991

10) Park, J.H., and Hong, S.H., "Optimization analysis of inductively coupled plasma torch for material processing by using local thermal equilibrium numerical models", J. Kor. Phys.
Soc, Vol. 31, 1997, pp.753-763

11) Seo, J.H., Park, J.M., and Hong, S.H., "Thermal plasma flow and equivalent circuit analyses on the electrical coupling in a DC-RF hybrid plasma torch", J. Kor. Phys. Soc, Vol. 54[1], 2009, pp.94-101 